\title{
Does Family Business Group Affiliation In Real Sector Firms Really Affect Their Performance? ${ }^{1}$
}

\author{
Ozcan Isik \\ Department of Banking and Finance, School of Applied Sciences \\ Cumhuriyet University, Sivas, Turkey
}

\begin{abstract}
In this study, we empirically examine the performance effect of group affiliation by comparing the performance of firms that belong to family business groups with the performance of independent firms. For this purpose, we use a sample of 193 Turkish firms (i.e. 90 group affiliated firms and 103 non-group firms) quoted on the Istanbul Stock Exchange (Borsa Istanbul) during the 2005-2012 period. Based on ROA and Tobin's $Q$ performance measures, the findings obtained from the FEVD estimator reveal that group membership does not always positively affect the financial performance of member firms. There exists a threshold effect of group affiliation, i.e. big group firms are better performers than both small group firms and stand-alone firms. Furthermore, when taken into account of firms' age, we find that positive effect of group affiliation is only valid for old group affiliated firms.
\end{abstract}

Keywords: Family Business Groups, Group Affiliation, Borsa Istanbul Stock Exchange, Turkey

\section{INTRODUCTION}

It is possible to express that the formation and development of business groups that exist in almost every country are influenced considerably by the historical, political, economic and socio-cultural factors of the countries. Business groups as an important element of capital markets dominate the economies of countries in all world economies (Leff, 1978; Khanna and Palepu, 2000a; Cheong et al., 2010; González et al., 2012). They are widely accepted as a prevalent organizational form in not only emerging but also developed economies. Despite the fact that the definition of a business group changes widely from one country to another, a business group can generally be defined as an organization where a family or individual can usually own a large number of member firms and be involved in their top management and/or board of directors. They also control them through pyramidal structures (La Porta et al., 1999; Cuervo-Cazurra, 2006; Claessens et al., 2006; Almeida and Wolfenzon, 2006; Gonenc and Hermes, 2008; Chang and Hong, 2000; among others). As Cuervo-Cazurra (2006) emphasizes, it is possible to mention three types of business groups according to their ownership structure. These are known as state-owned, widely-held, and family-owned business groups.

As in other underdeveloped countries, holding-centered Turkish family business groups, along with other business groups, have emerged as the result of policies that the state has pursued in order to accelerate economic development and industrialization. Family business groups as well as state-owned business groups have played vital and significant economic roles in the long-term development of the country and are accepted driving force of economic growth

\footnotetext{
1 This study called "Business group affiliation and firm performance: An empirical study for a comparison of firms affiliated with business groups with unaffiliated firms in the ISE" is derived from the doctoral thesis which is accepted by Institute of Erciyes University Social Sciences, Department of Accounting and Finance in 2013.
} 
(Bugra, 1994; Khanna and Yafeh, 2007; Çolpan and Hikino, 2008; Öztürk, 2012). The family business groups dominate a large proportion of the Turkish economy compared with other types of business groups (Gökşen and Üsdiken, 2001). Typically organized as a pyramidal structure, Turkish family business groups tend to diversify their activities by investing in many sectors. To do this, they use member firms which operate in more than two sectors. As a result, Turkish family-owned business groups control many firms operating in related or unrelated sectors such as trade, industry, and banking (Bugra, 1994; Öztürk, 2012). Therefore, they steer the economic activities of private sectors and make a huge contribution to the growth of the Turkish economy as in other countries. Firms affiliated with family business groups are extremely common among publicly quoted firms in Turkey and have a dominant position in the economy (Gunduz and Tatoglu, 2003; Gonenc, 2009; Isik and Soykan, 2013).

The performance of the firms operating under business groups has become one of the significant issues that are being discussed in the finance and strategy literature. There are many empirical studies that try to identify the influence of business group membership by comparing business-group firms with independent firms in terms of financial performance. However, the findings obtained from these studies indicate the effect of group membership on firm performance is uncertain. For example, Chang and Choi (1988) conclude that performance of Korean business-group firms is better than that of unaffiliated firms. This finding is supported by Keister (1998) for China, Khanna and Palepu (2000a) for Chile, Ghosh (2010) for India, Cheong et al. (2010) for Korea, Khanna and Rivkin (2001) for Taiwan, India, and Indonesia, and Chakrabarti et al. (2007) for Thailand, Indonesia, and Singapore. However, Choi and Cowing (1999) report that group membership in Korea in general leads to a worse performance with regards to group firms. Similar results are reported by Khanna and Rivkin (2001) for Argentina, George and Kabir (2008) for India, Gohar and Karacaer (2009) for Pakistan, Hernández-Trasobares and Galve-Górriz (2017) for Spanish. In addition to these results, empirical studies on many countries with different levels of institutional development reveal mixed results (i.e., positive, negative, or non-significant) regarding advantages of group membership in terms of accounting and stock market performance (see for example, Khanna and Palepu, 2000b; Chu, 2004; Lensink and Molen, 2010; He et al., 2013; Gunduz and Tatoglu, 2003; Gonenc et al., 2007; Selçuk, 2014; Carney et al., 2009; Zhang, 2011).

The fact that group membership causes different effects on performance of group affiliates can be explained by some potential benefits and costs of group membership. First, business groups are highly like to help affiliated firms to gain access to foreign capital and technology more easily (Khanna and Palepu, 2000b). Second, especially in cases where external markets are uncertain or limited with regards to financing opportunities, business groups can constitute an internal capital market by collecting funds from each member firm. In this way, the collected funds through internal capital markets are redistributed among member firms with the aim of using them more efficiently. This can allow the affiliates to meet the capital needs for financially constrained investment projects with high-profit potential and gain competitive advantages (Leff, 1978; Khanna and Yafeh, 2005; Gonenc et al., 2007). Third, when taken into account ownership structure of group firms, the presence of dominant shareholders in firms belonging to business groups can remedy for classical agency problem between professional managers and small shareholders on account of the monitoring effect (Fama and Jensen, 1983; Shleifer and Vishny, 1986).

As for possible costs of group affiliation, the fact that control is concentrated in the hands of dominant shareholders could lead to another agency issue between dominant and minority shareholders because of the expropriation effect (La Porta et al., 1999; Cuervo-Cazurra, 2006). Another cost of group affiliation can be associated with overinvestment issue. According to 
overinvestment hypothesis (Jensen, 1986), managers of group firms having higher free cash flows may tend to invest in projects with low-profit potential (Ferris et al., 2003). Thirdly, based on profit stability hypothesis, business groups may attach particular importance to the stability of profits instead of profit maximization for ensuring their survival (Ferris et al., 2003). Finally, In accordance with propping hypothesis, the dominant shareholders in business groups may subsidize group firms that are in financial distress, in spite of the fact that this does not coincide with other weak members of the group (Gonenc and Hermes, 2008; He et al., 2013).

This study is of great importance for the understanding of position of the holding-based family business groups in the Turkish economy. In this study, our main aim is to analyze empirically whether family business group membership has a beneficial or a detrimental effect in terms of financial performance of affiliated firms compared to independent firms. Our study aims to contribute to the existing business group literature in two ways. To our knowledge, our study is the first to examine whether or not the performance effect of group affiliation is associated with age and size of group firms. Another contribution of our study is that our performance model is mainly estimated through a new panel estimator, i.e. the fixed-effects (FE) vector decomposition (FEVD) developed by Plümper and Troeger (2007) and Plümper and Troeger (2011). Our findings from the FEVD estimator suggest that even though group membership usually improves performance of affiliated firms, we find a threshold effect of group affiliation. In other words, bigger group firms are better performers than both smaller group firms and stand-alone firms. Moreover, older affiliated firms are found to be better performers compared to both younger group affiliates and non-group firms.

The next section overviews the review of related studies and is followed by a presentation of our data, variables, estimation methodology employed in our study. The empirical results and our conclusion then follow.

\section{REVIEW OF RELATED STUDIES}

Chu (2004) investigates the influence of group affiliation on performance measured by the return rate of assets (ROA) and Tobin's $Q$ value by analyzing 763 Taiwan firms (340 member firms-423 independent firms) between 1997-1999. Regression results imply that firms' stock market performance improves if they are associated with large-scale business groups but their accounting performance deteriorates if they are associated with small-sized groups. These results demonstrate that group membership does not always create value for firms. Business group' size does matter with regards to the benefits and costs of group membership. As a result, there is a U-shaped association between profitability indicator and business group membership in Taiwan economies.

Based on a sample of 114 Chilean firms during 1988-1996, Khanna and Palepu (2000a) investigate whether or not affiliate firms provide an advantage from business group affiliation using both cross-sectional and panel estimation methods. In general terms, the results of their analyses imply that while group affiliation is positively related to accounting performance measured by ROA, It seems that there is a U-shaped curvilinear association between the level of diversification of groups and ROA. Besides, findings also suggest that size of groups is not associated with higher ROA.

On Istanbul stock exchange, Gunduz and Tatoglu (2003) compare the financial characteristics of 118 stand-alone firms with those of 84 business groups affiliated firms in order to determine the association between group membership and performance of the firms in 1999. According to the results of one-way analysis of variance and Kruskal Wallis tests, firms 
associated with diversified Turkish business groups are not significantly different from nongroup firms with regards to accounting and market-based performance measures and other performance measures.

In Turkey, Gonenc et al. (2007) investigate whether the firms in business groups have created the internal capital market by comparing the performance of 123 affiliated firms and 77 unaffiliated firms that are listed on Istanbul stock exchange in 2000. Analysis results indicate that business group affiliation is associated with higher ROA but there is no meaningful linkage between business group affiliation and stock market performance (i.e. Tobin's Q).

In another study using a sample of 255 Turkish firms traded on the Borsa Istanbul Stock Exchange during 2006-2012, Selcuk (2014) explores how diversification-performance relation is affected by business group affiliation. Her analysis results suggest that stock market measured (Tobin's q) is positively associated with group affiliation but this linkage is not statistically significant. As for the influence of group affiliation on performance-diversification relation, Turkish firms that are belong to diversified business groups cannot benefit from the effect of diversification.

On Bombay stock exchange, Khanna and Palepu (2000b) explore the performance of 655 group firms relative to 654 non-group firms in 1993 using OLS regressions. Tobin's Q and return on assets (ROA) are used as performance measures in order to examine the impact of group membership and group diversification on firm performance. According to the results, Tobin's $Q$ is not significantly affected group affiliation. Only, firms affiliated with most diversified business groups perform better than both other group firms and independent firms. When the ROA model is taken into consideration, the results imply that group affiliation is negatively and significantly related to ROA. Moreover, least and intermediate diversified group firms underperform other group firms and stand-alone firms. Besides, there exists an inverted-U shape association between group diversification and firm performance measures.

George and Kabir (2008), examining the issue as to how business group affiliation influences firm financial performance, use a sample of 844 Indian listed firms (368 affiliated firms-476 unaffiliated firms) during 1998-2000. The authors conclude that business group affiliation has a damping impact on firm financial performance measured return on assets according to the pooled OLS regressions.

Using 1342 firm-level data, Lensink and Molen (2010) examine the impact of business group affiliation on firm performance in India for the time period 1996-2001. The market-to-book ratio and the return on assets are used to measure firm performance in the study. Based on Fixed Effects Vector Decomposition estimator, while affiliation with a business group increases firm value, it decreases performance of affiliated firms when ROA is taken into consideration.

Based on firm level data in India for the period between 1996 and 2006, Ghosh (2010) empirically analyzes the influence of group affiliation on firm financial performance in terms of group size and diversity. According to regressions results, business groups affiliated firms perform better compare to non-group affiliated firms. In addition to these, while firms affiliated with small and mid-sized business groups are better performers than both non-group firms and firms belonging to large-sized business groups, a surge in group diversity leads to higher firm value.

Based on a sample of 535 Chinese listed firms operating different industries for the time period of 1988-1990, Keister (1998) analyzes how business group affiliation affect performance of 
group firms. Results obtained from the random effects GLS estimator reveal that Interlocking directorates and financial firms within the Chinese business groups significantly and positively affect profits and productivity of affiliated firms.

Carney et al. (2009), using the dataset of Chinese listed firms for two different years (i.e. 1999 and 2004), explore the performance of business groups affiliated firms. Estimation results from the OLS and the 2SLS regressions suggest that group firms have higher ROA in 1999. However, when the model specification is re-estimated for the year 2004, the positive influence of the business group membership tends to disappear in 2004.

Employing panel data on 62 Chinese listed firms (46 group firms-16 non-group firms) operating in textile industry from 2001 through 2005, Zhang (2011) examines the linkage between diversification strategies and group affiliation. The results obtained from panel data regressions imply that when Tobin's $Q$ is used as a performance measure, firms belonging to business groups benefit from unrelated diversification activities compare to non-group members. The impact of group members' related diversification on performance is significantly negative for both Tobin's $Q$ and ROA, suggesting that related diversification strategy pursued by group members leads to lower performance than that of non-group firms.

He et al. (2013), analyzing empirically how Chinese business groups contribute to the performance of group affiliated firms during 1998-2006 period, report that while group membership is not associated with accounting performance (i.e. ROA and ROE), firms that are belong to business groups have higher Tobin's $Q$ value. Another result reached in the study is that firms associated with business groups are highly likely to cope with the financial constraints regarding external funding.

Employing a sample of 182 listed firms (i.e., 119 affiliated firms and 63 unaffiliated firms) operating in the manufacturing industry in Korea over the period from 1975 to 1984 period, Chang and Choi (1988) analyze the linkage between business group affiliation and profitability of firm. Their empirical results imply that business group affiliation in the manufacturing sector improves firm profitability.

Choi and Cowing (1999) analyze the linkage between business group affiliation and performance of firm using a sample of 252 Korean publicly listed quoted firms (i.e., 91 group firms and 161 non-group firms) from manufacturing sector for the period between 1985 and 1993. In their analysis, the research is conducted for each of years separately and various subperiods. The results of the research show that group affiliated firms generally have lower annual profit rates when compared to independent firms. More specifically, based on subperiods analysis, it is found that the group firms have had lower annual profit rates compared to non-group firms until 1989, and after 1989 the difference between the two types of firms decrease. Nevertheless, only large-scale business group firms have slightly higher growth rates and considerably less variability in annual profit rates after 1989.

Hernández-Trasobares and Galve-Górriz (2017) explore the influence of diversification strategies of different type of business groups and family control on financial performance for 99 firms registered in the Spanish stock market between the years from 2000 to 2005. Their results indicate that family-controlled business groups exhibit a significant and negative association with Tobin's Q, compared to non-family business groups. Besides, the authors report that there is no relation between diversification degree and performance. 
Using a sample of 166 firms (i.e., 86 group affiliated firms-80 non-group firms) that are traded on the Karachi Stock Exchange in Pakistan between the years 2002-2006, Gohar and Karacaer (2009) analyze whether business groups affiliation has an impact on the performance of firm. Estimation results from OLS suggest that the firms affiliated with business groups perform worse than the non-affiliated firms in terms of ROA, OROA, and Tobin's Q. Besides, a similar inverse linkage between group diversity level and performance measures is observed in the study. In other words, firms associated with least, intermediate and most diversified groups have lower performance compared to non-affiliated firms.

Chakrabarti et al. (2007) investigate empirically whether business group membership has an impact on performance-diversification linkage by analyzing 3.117 (2175 group firms-942 nongroup firms) firms that operate in manufacturing sectors from 6 East Asia countries (i.e. Japan, Korea, Thailand, Indonesia, Singapore, and Malaysia) for the time period of 1988-2003. Estimation finding from panel data analysis using ROA as a performance indicator indicate that business group affiliated firms benefit more from diversification activities compared to nongroup affiliated ones in countries such as Thailand, Indonesia, and Singapore.

Khanna and Rivkin (2001), who consider business groups as a reaction to high transaction costs and market insufficiencies, have developed various hypotheses about the impact of group membership on firm profitability measured by ROA using a large dataset compiled from local sources (i.e. 14 different emerging countries). According to results, group membership significantly affects industry membership as well as profitability in 12 emerging countries analyzed. However, findings indicate that the sources of long-term differences in profitability may vary based on institutional conditions. In more detail, results from the regression models reveal that compared to independent firms, group affiliated firms are better performers in Taiwan, India, and Indonesia. Whereas, group controlled firms are worse performers compared to focused firms in Argentina. In addition to these findings, the authors emphasize that there is a balance between the benefits and costs of group membership in Turkey, Thailand, Korea, Mexico, and Brazil.

In a study on Mexican banking industry, Chavarín (2016) explores whether there exists a performance difference between the business group banks and the banks not associated with groups for 45 deposit banks during 2007-2011. Empirical results from panel data analyses imply that the influence of group affiliation is negative and statistically significant, meaning that the performance of business group banks in terms of accounting measures (i.e. ROAA and ROAE) is worse than that of non-group banks.

\section{Sample and data source}

\section{DATA}

Our sample is based on an unbalanced panel dataset of 193 firms (i.e., 90 group firms and 103 non-group firms) quoted on the Borsa Istanbul Stock Exchange during the 2005-2012 period. These quoted firms operate in 8 different sectors of the Borsa Istanbul. We obtain the firmspecific financial data from FINNET database. Firms having negative equity capital are excluded from the sample. Financial firms as well as firms having less than five years of available data are also dropped from our sample.

\section{Dependent and independent variables}

Firm performance is measured based on both accounting and stock market performance measures, i.e., ROA and Tobin's Q. ROA is defined as net income divided by total assets. Market based measure of financial performance, Tobin's $Q$, is calculated as the market value of equity plus the book value of debt divided by the book value of total assets. The extreme outliers of 
performance measures could lead to potential biases of estimations. They are determined through the procedure of interquartile range of the STATA software and removed from both ROA and Tobin's $Q$ series.

Despite the fact that different definitions for business group affiliation are employed by different authors in the business group literature, in this study, we benefit from an ownership criterion to define group firms. In accordance with shareholder structure of listed firms, a listed firm is classified as a group firm if its largest shareholder is a family holding firm. Thus, group firms represented by a dummy variable take the value of 1 when the quoted firm is associated with a family holding firm, otherwise 0 .

To better understand whether the performance effect of group affiliation is associated with age and size of group firms, we split up group affiliated firms into small (young) group firms and big (old) group firms taking into account sample firms' size (age). Once again we use dummy variables for these firms. Therefore, small (big) group firms take value of 1 if an affiliated firm's size is less (greater) than the median value of sample firms' size. Likewise, young (old) group firms take value of 1 if a group firm's age is less (larger) than the median value of age of firms in the sample. As a result, we construct five different dummy variables (i.e. group firms, small (big) group firms and young (old) group firms) to measure group affiliation.

In line with prior business groups studies (e.g., Choi and Cowing, 1999; Gonenc et al., 2007; He et al., 2013; Lensink and van der Molen, 2010; Zhang, 2011; among others) we also use firmlevel control variables such as firms size, liquidity, sort-term debt, long-term debt, stock return volatility and firm age. Firm size is expressed as the natural logarithm of the book value of total assets. Liquidity level is measured by the ratio of current assets to total assets. While sort-term debt is measured as short-term liabilities divided by total assets, long-term debt is defined as the ratio of the firm's long-term liabilities to its total assets. Stock return volatility representing a firm-specific risk is calculated by the standard deviation of monthly stock returns for the previous twelve months. Finally, firm age is defined as the natural log of the number of years since the firm's inception. from the founding year. Besides, the dummy variables for each industry and year are included in regression specifications to control for industry and year effects.

\section{Descriptive statistics}

The number of sample firms in each sector as well as the number of group and non-groups firms is reported in Table 1.

Table 1. Breakdown of Group and Non-Group Firms by Sector

\begin{tabular}{lccc}
\hline Sector & All Firms & Group firms & Non-group firms \\
\hline Mining & 2 & 2 & - \\
Manufacturing & 143 & 69 & 74 \\
Electricity, Gas and Water & 4 & 3 & 1 \\
Construction & 2 & 1 & 1 \\
Wholesale and Retail Trade, Hotels and Restaurants & 17 & 9 & 8 \\
Transportation and Telecommunication & 6 & 1 & 5 \\
Education, Health and Sports & 6 & - & 8 \\
Technology & 13 & 5 & 103 \\
Total & 193 & 90 & \\
\hline
\end{tabular}

Summary statistics for all sample firms listed on the Borsa Istanbul Stock Exchange are provided in Table 2. The average ROA of the sample quoted firms is $3.32 \%$ and the mean value of Tobin's $Q$ is approximately 1.28. Group firms represent about $46 \%$ of the Turkish sample 
firms during the 2005-2012 period. While approximately $18 \%$ (28\%) of quoted firms are small (big) group firms, about 19\% (27\%) of quoted firms are young (old) group firms.

Table 2. Summary statistics for all firms

\begin{tabular}{lllllll}
\hline Variable & N & Max & Min & Mean & Median & SD \\
\hline ROA & 1461 & .33120 & -.2711 & .0332 & .0342 & .0896 \\
Tobin's Q & 1443 & 3.4698 & .2160 & 1.2760 & 1.1387 & .5491 \\
Group firms & 1507 & 1 & 0 & .4625 & 0 & .4988 \\
Small group firms & 1507 & 1 & 0 & .1785 & 0 & .3917 \\
Big group firms & 1507 & 1 & 0 & .2840 & 0 & .4511 \\
Young group firms & 1507 & 1 & 0 & .1884 & 0 & .3994 \\
Old group firms & 1507 & 1 & 0 & .2741 & 0 & .4462 \\
Total assets & 1507 & 18780.9 & 6.14 & 906.8745 & 209.82 & 2194.363 \\
Liquidity & 1507 & .9998 & .0010 & .5054 & .5004 & .2232 \\
Short-term debt & 1507 & 4.1651 & .0006 & .3364 & .2939 & .2530 \\
Long-term debt & 1507 & 3.0466 & 0 & .1319 & .0792 & .1759 \\
Volatility & 1410 & 5.886 & 0 & .0206 & .0008 & .1831 \\
Firm age & 1507 & 101 & 2 & 34.0557 & 35 & 14.7249 \\
\hline
\end{tabular}

Note: Figures on total assets is expressed in millions Turkish Lira (TRY).

The mean (median) differences between two groups are tested employing $t$-test (Wilcoxon rank-sum test). The results of these tests are reported in Table 3, respectively. As can be seen in Table 3, In spite of the fact that the mean (median) value of Tobin's q does not significantly differ between firms affiliated with family business groups and unaffiliated firms, the mean (median) value of ROA is significantly higher for members of family business groups. Total assets are significantly higher for affiliated firms, whereas liquidity level, sort-term debt and long term debt (only significant in $t$-test) are significantly higher for independent firms. However, the difference with regards to stock return volatility between the two groups is statistically insignificant. The mean value of age for firms in family business groups is similar to that of independent firms, suggesting that there is no significant difference in terms of mean value of age between them. However, the median difference test that we perform shows that the median age of affiliated firms is significantly bigger than that of unaffiliated.

Table 3. Summary statistics both group and non-group firms

\begin{tabular}{lllllll}
\hline Non-group firms & & & & & \\
Variable & Obs. & Max & Min & Mean & Median & SD \\
\hline Return on assets & 775 & .3312 & -.2672 & .0286 & .0306 & .0920 \\
Tobin-Q & 758 & 3.4698 & .2160 & 1.2836 & 1.1363 & .5603 \\
Total assets & 810 & 18780.9 & 6.14 & 720.2224 & 176.51 & 2094.845 \\
Liquidity & 810 & .9998 & .0056 & $.5216^{* * *}$ & $.5251^{* * *}$ & .2345 \\
Short-term debt & 810 & 2.3977 & .0006 & $.3473^{*}$ & $.3021^{*}$ & .2441 \\
Long-term debt & 810 & 3.0466 & 0 & $.1417^{* *}$ & .0766 & .2090 \\
Volatility & 769 & 1.3028 & 0 & .0137 & .0008 & .0706 \\
Firm age & 810 & 101 & 5 & 33.8099 & 34 & 16.0035 \\
\hline Group Firms & & & & & Median & SD \\
\hline Variable & $\mathbf{0 b s .}$ & Max & Min & Mean & $.0412^{* *}$ & .0866 \\
\hline Return on assets & 686 & .3282 & -.2711 & $.0383^{* *}$ & 1.1467 & .5368 \\
Tobin-Q & 685 & 3.4157 & .2927 & 1.2677 & $296.42^{* * *}$ & 2287.059 \\
Total assets & 697 & 17114.1 & 7.8 & $1123.787^{* * *}$ & .4813 & .2079 \\
Liquidity & 697 & .9996 & .0010 & .4865 & .2837 & .2626 \\
Short-term debt & 697 & 4.1651 & .0047 & .3237 & .0816 & .1263 \\
Long-term debt & 697 & .8465 & .0001 & .1205 & .0289 & 3608 \\
Volatility & 641 & 5.8864 & 0 & 34.3415 & .2602 \\
Firm age & 697 & 77 & 2 & & 13.0886 \\
\hline
\end{tabular}


Notes: This table shows summary statistics for both group and non-group firms and the results of $t$-test and Wilcoxon rank-sum test to compare the difference of means and medians between two types of firms. Figures on total assets are expressed in millions Turkish Lira (TRY). Statistical significance at the one, five-, and ten-percent level is indicated by ${ }^{*},{ }^{* *}$ and ${ }^{* * *}$, respectively.

\section{METHODOLOGY}

We specify the following regression equation similar to that of Khanna and Palepu (2000b), Chu (2004), Gonenc et al., (2007), Ghosh (2010), and Lensink and van der Molen (2010) to explore the influence of group affiliation on firm performance:

Performance $_{i t}=\alpha+\beta$ Group affiliation $_{i}+\sum_{\mathrm{j}=1}^{6} \lambda_{\mathrm{j}}$ Firm spesific variables $_{\mathrm{it}}+\psi_{\mathrm{i}}+\xi_{\mathrm{t}}+\mu_{\mathrm{i}}+\varepsilon_{\mathrm{it}}$ (1)

In this specification Performance ${ }_{i t}$, our dependent variable, is measured as ROA and TQ-value. $\alpha$ is the constant, Group affiliation ${ }_{i}$ is a time-invariant dummy variable representing group firms and equals to 1 if the firm belongs to a family business group, and 0 otherwise. Firm spesific variables ${ }_{i t}$ contains a set of observed time-varying firm-specific independent variables which change across $i$ and $t, \psi_{\mathrm{i}}$ is a set of time-invariant industry dummies, $\xi_{\mathrm{t}}$ represents a set of year dummies, $\mu_{\mathrm{i}}$ denotes unobserved time-invariant unit (firm-specific) effects, and $\varepsilon_{i t}$ is the error term of performance model.

Our performance model could be estimated traditional panel data estimators such as pooled OLS (POLS), random effects (RE), and fixed effects (FE) estimators. If the $\mu_{\mathrm{i}}$, unobservable heterogeneity or unit-specific unobserved effects, is not correlated with each of observed independent variables, the POLS or the RE estimation of our regression model is consistent. However, If the $\mu_{\mathrm{i}}$ is present and correlated with observed independent variables in our model specification formulized in Eq. (1), both the POLS and the RE technique will no longer be consistent. We can cope with the problem of inconsistency by employing the FE. The FE technique employing only within variance for estimations cannot, however, estimate the influence of time-invariant elements such as group affiliation variable that is crucial to our analysis and industry dummy variables owing to within transformation (Wooldridge, 2002; Baltagi, 2005; Cameron and Trivedi, 2005; Baum, 2006; Adkins and Hill, 2011). In this case, we need alternative estimation methods such as Hausman-Taylor (HT) or fixed-effects vector decomposition (FEVD). Employing Monte Carlo simulations, Plümper and Troeger (2007, 2011) have demonstrated that the FEVD method performs better than traditional techniques (i.e. the HT, the POLS and the RE) in the presence of time-varying variables correlated with unit specific effects for small samples.

The procedure suggested by Plümper and Troeger $(2007,2011)$ have composed of three stages. Firstly, by employing the following model specified in Eq. (2), the estimates of the unit effects $\hat{\mu}_{i}$ are obtained from a FE estimate of our baseline model without time-invariant regressors:

$$
\text { Performance }_{i t}=\alpha_{i}+\sum_{j=1}^{6} \lambda_{j} \text { Firm spesific variables }{ }_{i t}+\xi_{t}+\varepsilon_{i t}
$$

Secondly, the estimated unit effects $\hat{\mu}_{i}$ is only regressed on all of time-invariant regressors of our original model (i.e. group affiliation and industry dummies), meaning that $\hat{\mu}_{i}$ is decomposed into two part (i.e. a part explained by group affiliation and a set of industry dummies and an unexplained part represented by residuals). In this stage, by using POLS estimation procedure, the residuals, $\mathrm{h}_{\mathrm{i}}$, are obtained: 


$$
\hat{\mu}_{\mathrm{i}}=v+\beta \text { Group affiliation }_{\mathrm{i}}+\psi_{\mathrm{i}}+\mathrm{h}_{\mathrm{i}}
$$

Lastly, as shown below, we re-estimate original model specified in Eq. (1) through the POLS procedure by adding $h_{i}$ which is estimated from Eq. (3) instead of $\mu_{i}$. Therefore, our final regression model to be estimated takes the form:

Performance $_{i t}=\alpha+\beta$ Group affiliaiton $_{\mathrm{i}}+\sum_{\mathrm{m}=1}^{6} \lambda_{\mathrm{m}}$ Firm spesific variables $_{\mathrm{it}}+\psi_{\mathrm{i}}+\xi_{\mathrm{t}}+\mathrm{h}_{\mathrm{i}}+\varepsilon_{\mathrm{it}}$ (4)

Plümper and Troeger $(2007,2011)$ have demonstrated that $h_{i}$ by construction is not mathematically related to time-invariant variables in above specification. The estimated coefficient of $h_{i}$ in the last stage should be approximately equivalent to one when applied the FEVD procedure.

\section{EMPIRICAL RESULTS}

Regression results from our performance model taking ROA and Tobin's $Q$ as the dependent variable are reported in Table 5. From the first column of Table 5, the coefficient on group firms is significantly positive, thus showing that family business group affiliation tends to enhance accounting performance of firm. More specifically, group firms seem to earn 37.65\% more returns relative to independent firms (this is calculated as the estimated coefficient of group firms/average ROA value). This finding showing that Turkish group firms make use of the membership of the family business group is similar to those of Gonenc et al., (2007) for Turkey, Ghosh (2010) for India, Cheong et al. (2010) for Korea. However, this finding contradicts those of Chu (2004) for Taiwan, George and Kabir (2008) for India, He et al. (2013) for Chinese, Choi and Cowing (1999) for Korea, and Gohar and Karacaer (2009) for Pakistan. We re-estimate our regression equation by replacing the variable of group firms with the variables of small and big group firms to further understand if or not there exists a threshold effect based on the size of group firms in model 2 of Table 5. Empirical results imply that while small group firms are significantly negatively correlated with ROA, big group firms are found to be positively and significantly related to ROA, suggesting that there exists "a threshold effect" of group affiliation. These results indicate that size matters for group firms. Similarly, Chu (2004) reports that accounting performance (ROA) is negatively related to small-sized group firms but positively linked with large-sized group firms. To better understand how group firms' performance is affected by firm age, our regression equation is again re-estimated with young and old group firms instead of group firms in model 3 of Table 5. The results shown in the third column suggest that even though the coefficient estimates for both group firms are positive and significant, old group firms tend to be more profitable than other firms. These results imply that firm age is important for group affiliates. As for the control variable, higher leverage ratios and size are associated with lower ROA, while greater liquidity and age significantly increase ROA. Return volatility is, however, not found to be significant.

In terms of stock market performance measure, Tobin's $Q$, we reach similar result for group firms as is the case with ROA model. In model 4, firms that are group members appear to have greater Tobin's $Q$ value compared to non-group firms, i.e. Tobin's $Q$ in group firms is approximately $20.27 \%$ higher than in non-group focused firms (this figure is calculated as the coefficient estimate/average Tobin's $Q$ value). This finding is in line with the earlier findings of Chu (2004) for Taiwan, Ghosh (2010) for India, Lensink and Molen (2010) for India, and He et al. (2013) for China but contradicts those of Khanna and Palepu, (2000b) for India, Gohar and Karacaer (2009) for Pakistan, Hernández-Trasobares and Galve-Górriz (2017) for Spain and Selcuk (2014) for Turkey. In model 5 of Table 5, when we employ small and big group firms 
dummy variables instead of group firms dummy variable to investigate the existence of the threshold effect of group affiliation, our result again indicates that big (small) group firms have a positive (negative) and significant relation to Tobin's Q, implying that big group firms outperform other firms. The result demonstrating that for group firms, size does really matter for better performance is supported by Chu (2004) for firms operating in Taiwan Stock Exchange Market. From the model 6 of Table 5, the impact of group affiliation is separated into two variables, i.e. young and old group firms. While the estimated coefficient for old group firms is found to be positive and significant, the coefficient for young group firms is found to be negative and insignificant. These results mean that old group firms are better performers than both young group firms and stand-alone firms. According to these findings, we can conclude that firm age does matter for group firms as well. Regarding the impact of control variables on stock market performance, we observe that although higher size and age are related to lower Tobin's $Q$ value, greater liquidity and leverage levels lead to higher market performance. Moreover, volatility has no significant impact on market performance.

Table 5. Results of panel FEVD regressions

\begin{tabular}{|c|c|c|c|c|c|c|}
\hline & ROA & ROA & ROA & Tobin-Q & Tobin-Q & Tobin-Q \\
\hline & Model I & Model II & Model III & Model IV & Model V & Model VI \\
\hline Group firm & $\begin{array}{l}.0125^{* * *} \\
(.0033)\end{array}$ & & & $\begin{array}{l}.2587^{* * *} \\
(.0050)\end{array}$ & & \\
\hline Small Group Firm & & $\begin{array}{l}-.0215^{* * *} \\
(.0045)\end{array}$ & & & $\begin{array}{l}-.2986^{* * *} \\
(.0115)\end{array}$ & \\
\hline Big Group Firm & & $\begin{array}{l}.0394^{* * *} \\
(.0041)\end{array}$ & & & $\begin{array}{l}.6624^{* * *} \\
(.0149)\end{array}$ & \\
\hline Young Group Firm & & & $\begin{array}{l}.0087^{*} \\
(.0046)\end{array}$ & & & $\begin{array}{l}-.0089 \\
(.0109)\end{array}$ \\
\hline Old Group Firm & & & $\begin{array}{l}.0169^{* * *} \\
(.0039)\end{array}$ & & & $\begin{array}{l}.5039 * * * \\
(.0126)\end{array}$ \\
\hline Ln(assets) & $\begin{array}{l}-.0033^{* *} \\
.(0014)\end{array}$ & $\begin{array}{l}-.0032^{* *} \\
(.0015)\end{array}$ & $\begin{array}{l}-.0032^{* *} \\
(.0014)\end{array}$ & $\begin{array}{l}-.3831^{* * *} \\
(.0067)\end{array}$ & $\begin{array}{l}-.3852^{* * *} \\
(.0074)\end{array}$ & $\begin{array}{l}-.3830^{* * *} \\
(.0067)\end{array}$ \\
\hline Liquidity & $\begin{array}{l}.0893^{* * *} \\
(.0120)\end{array}$ & $\begin{array}{l}.0893^{* * *} \\
(.0120)\end{array}$ & $\begin{array}{l}.0890^{* * *} \\
(.0120)\end{array}$ & $\begin{array}{l}.1504^{* *} \\
(.0530)\end{array}$ & $\begin{array}{l}.1512^{* *} \\
.0528)\end{array}$ & $\begin{array}{l}.1490^{* *} \\
(.0528)\end{array}$ \\
\hline Short-term debt & $\begin{array}{l}-.0501^{* * *} \\
(.0168)\end{array}$ & $\begin{array}{l}-.0501^{* * *} \\
(.0168)\end{array}$ & $\begin{array}{l}-.0502^{* * *} \\
(.0169)\end{array}$ & $\begin{array}{l}.6873^{* * *} \\
(.0389)\end{array}$ & $\begin{array}{l}.6856 * * * \\
(.0389)\end{array}$ & $\begin{array}{l}.6885^{* * *} \\
(.0392)\end{array}$ \\
\hline Long-term debt & $\begin{array}{l}-.0381^{* * *} \\
(.0113)\end{array}$ & $\begin{array}{l}-.0382^{* * *} \\
(.0114)\end{array}$ & $\begin{array}{l}-.0384^{* * *} \\
(.0114)\end{array}$ & $\begin{array}{l}.8501^{* * *} \\
(.0664)\end{array}$ & $\begin{array}{l}.8529 * * * \\
(.0667)\end{array}$ & $\begin{array}{l}.8499 * * * \\
(.0666)\end{array}$ \\
\hline Volatility & $\begin{array}{l}.0026 \\
(.0069)\end{array}$ & $\begin{array}{l}.0025 \\
(.0069)\end{array}$ & $\begin{array}{l}.0027 \\
(.0069)\end{array}$ & $\begin{array}{l}.0343 \\
(.0426)\end{array}$ & $\begin{array}{l}.0348 \\
(.0431)\end{array}$ & $\begin{array}{l}.0341 \\
(.0426)\end{array}$ \\
\hline Ln(age) & $\begin{array}{l}.0315^{* * *} \\
(.0040)\end{array}$ & $\begin{array}{l}.0315^{* * *} \\
(.0040)\end{array}$ & $\begin{array}{l}.0308^{* * *} \\
(.0047)\end{array}$ & $\begin{array}{l}-.6187^{* * *} \\
(.0090)\end{array}$ & $\begin{array}{l}-.6179 * * * \\
(.0098)\end{array}$ & $\begin{array}{l}-.6284^{* * *} \\
(.0131)\end{array}$ \\
\hline$h_{i}$ & $\begin{array}{l}1.000^{* * *} \\
(.0391)\end{array}$ & $\begin{array}{l}1.000^{* * *} \\
(.0394)\end{array}$ & $\begin{array}{l}1.000^{* * *} \\
(.0393)\end{array}$ & $\begin{array}{l}1.000^{* * *} \\
(.0126)\end{array}$ & $\begin{array}{l}1.000^{* * *} \\
(.0127)\end{array}$ & $\begin{array}{l}1.000^{* * *} \\
(.0131)\end{array}$ \\
\hline Intercept & $\begin{array}{l}.0031 \\
(.0254) \\
\end{array}$ & $\begin{array}{l}-.0010 \\
(.0254)\end{array}$ & $\begin{array}{l}.0086 \\
(.0269)\end{array}$ & $\begin{array}{l}5.6841^{* * *} \\
(.0632)\end{array}$ & $\begin{array}{l}5.6930^{* * *} \\
(.0636)\end{array}$ & $\begin{array}{l}5.7097^{* * *} \\
(.0691)\end{array}$ \\
\hline R-squared & .5922 & .5922 & 0.5922 & .6775 & .6776 & .6776 \\
\hline Adj-R-squared & .5857 & .5855 & .5856 & .6724 & .6723 & .6723 \\
\hline RMSE & .05699 & .05677 & .05677 & .30735 & .30740 & .30739 \\
\hline Observations & 1366 & 1366 & 1366 & 1351 & 1351 & 1351 \\
\hline
\end{tabular}

Notes: Standard errors shown in parentheses are corrected for heteroskedasticity with the Huber-White sandwich estimator for variance. All regression models include dummy variables for each industry and each year of the sample period, but the results are not reported. The variable $\mathbf{h}_{\mathbf{i}}$ denotes the unobserved unit heterogeneity (i.e. the unexplained part) added to Eq. (4). The symbols ${ }^{* * *}, * *$, and ${ }^{*}$ indicate significance levels of $1 \%, 5 \%$ and $10 \%$, respectively. 


\section{CONCLUSIONS}

In this study, we empirically examine the association between family business group affiliation and firm financial performance, with the aim of understanding whether the performance effect of group affiliation is associated with age and size of group firms. Our study contains a total of 193 firms quoted on the Istanbul Stock Exchange (Borsa Istanbul) during the 2005-2012 period. From these listed firms, 90 firms are identified as family business group firms and 103 firms are independent firms. In order to explore the relation between family business group affiliation and performance of firms, the differences in firm size, liquidity level, financial risk measured by sort-term and long-term leverage, stock return volatility, and firm age are controlled for.

The findings obtained from the FEVD estimator in our study demonstrate that: (i) based on accounting performance measure (ROA), Turkish firms that are belong to family business groups significantly perform better than unaffiliated ones; (ii) While ROA is positively related to large-sized group firms, it is negatively linked with small-sized group firms; (iii) old group firms are more profitable than young group firms and other firms; (vi) when the results are examined by stock market measure (Tobin's Q), firms that are group members seem to have higher Tobin's Q value compared to non-group firms; (v) big group firms outperform other firms; (vi) older group firms are better performers than both young group firms and standalone firms.

Regarding main massage of this study, our results emphasize that although the firms that operate under a family business group affiliation generally perform better than the other ones; the performance effect of group affiliation is associated with age and size of group firms. As a consequence, our findings indicate that family business group affiliation cannot always create value for affiliated firms.

In this study, we only take family business groups into account rather than other business groups. Given the importance of business groups as a source of economic growth, it could be studied whether state-owned and widely-held business groups as well as family business groups create value for group affiliates. The findings of our study should not be interpreted in terms of other business groups in Turkey as well as business groups in other developing countries. For future research, different estimation techniques permitting the inclusion of time-invariant variables can be used to analyze the association between group affiliation and firm financial performance.

\section{References}

Adkins, L. C., and R. C. Hill. (2011). Using Stata for Principles of Econometrics. 4th ed., John Wiley\&Sons Inc: Hoboken.

Almeida H.V. and D. Wolfenzon. (2006). A Theory of Pyramidal Ownership and Family Business Groups. The Journal of Finance, 61(6), 2637-2680.

Bugra, A. (1994). State and business in modern Turkey: A comparative study, New York: SUNY Press.

Baltagi, B.H. (2005). Econometric Analysis of Panel Data, 3rd ed., John Wiley\&Sons Inc: Chichester.

Baum, C. F. (2006). An introduction to modern econometrics using Stata. Texas: Stata press.

Cameron, A. C., and Trivedi, P. K. (2005). Microeconometrics: Methods and Applications. New York: Cambridge University Press.

Carney, M., Shapiro, D., and Tang, Y. (2009). Business group performance in China: Ownership and temporal considerations. Management and Organization Review, 5(2), 167-193.

Chakrabarti, A., K. Singh and I. Mahmood. (2007).” Diversification and Performance: Evidence From East Asian Firms". Strategic Management Journal, 28(2), 101-120. 
Chang S.J. and U. Choi. (1988), Strategy, Structure and Performance of Korean Business Groups: A Transactions Cost Approach. The Journal of Industrial Economics, 37(2), 141-158.

Chang, S.J. and J. Hong. (2000). "Economic Performance of Group-Affiliated Companies in Korea: Intragroup Resource Sharing and Internal Business Transactions". The Academy of Management Journal, 43(3), 429-448.

Chavarín, R. (2016). Profitability in Banks Affiliated to a Business Group: Evidence from Mexico. Emerging Markets Finance and Trade, 52(8), 1892-1909.

Cheong, K. S., Choo, K., and Lee, K. (2010). Understanding the behavior of business groups: A dynamic model and empirical analysis. Journal of Economic Behavior \& Organization, 76(2), 141-152.

Choi, J.P. and T.G. Cowing (1999). Firm Behavior and Group Affiliation: The Strategic Role of Corporate Grouping For Korean Firms. Journal of Asian Economics, 10(2), 195-209.

Chu, W. (2004). Are group-affiliated firms really more profitable than nonaffiliated?. Small Business Economics, 22(5), 391-405.

Claessens, S., Fan, J. P., \& Lang, L. H. (2006). The benefits and costs of group affiliation: Evidence from East Asia. Emerging Markets Review, 7(1), 1-26.

Cuervo-Cazurra, A. (2006). Business groups and their types. Asia Pacific Journal of Management, 23(4), 419-437.

Çolpan, A. M., and Hikino, T. (2008). Türkiye'nin Büyük Şirketler Kesiminde Işletme Gruplarinin Iktisadi Rolü ve Çeşitlendirme Stratejileri. Journal of Management Research/Yonetim Arastirmalari Dergisi, 8(1-2): 23-58.

Fama, E. F., and Jensen, M. C. (1983). Separation of ownership and control. The journal of law and Economics, 26(2), 301-325.

Ferris, S. P., Kim, K. A., and Kitsabunnarat, P. (2003). The costs (and benefits?) of diversified business groups: The case of Korean chaebols. Journal of Banking \& Finance, 27(2), 251-273.

George, R., and Kabir, R. (2008). Business groups and profit redistribution: A boon or bane for firms?. Journal of Business Research, 61(9), 1004-1014.

Ghosh, S. (2010). Affiliation and firm performance: evidence from Indian business groups. The Manchester School, 78(3), 183-200.

Gonenc, H., Kan, O. B., and Karadagli, E. C. (2007). Business groups and internal capital markets. Emerging markets finance and trade, 43(2), 63-81.

Gonenc, H., and Hermes, N. (2008). Propping: Evidence from new share issues of Turkish business group firms. Journal of Multinational Financial Management, 18(3), 261-275.

Gonenc, H. (2009). How do business group firms utilize internal capital markets?. International Journal of Managerial Finance, 5(4), 360-375.

González, M., Guzmán, A., Pombo, C., and Trujillo, M. A. (2012). Family firms and financial performance: The cost of growing. Emerging Markets Review, 13(4), 626-649.

Gökşen, N.S. and B. Üsdiken. (2001). Uniformity and Diversity in Turkish Business Groups: Effects of Scale and Time of Founding. British Journal of Management. 12(4), 325-340.

Gunduz, L., and Tatoglu, E. (2003). A comparison of the financial characteristics of group affiliated and independent firms in Turkey. European Business Review, 15(1), 48-54.

He, J., Mao, X., Rui, O. M., and Zha, X. (2013). Business groups in China. Journal of Corporate Finance, 22, 166-192.

Hernández-Trasobares, A., and Galve-Górriz, C. (2017). Diversification and family control as determinants of performance: A study of listed business groups. European Research on Management and Business Economics, 23(1), 46-54.

Isik, O., and Soykan, M. E. (2013). Large shareholders and firm performance: Evidence from Turkey. European Scientific Journal, 9(25), 23-37.

Jensen, M.C., (1986). Agency costs of free cash flow, corporate finance and takeovers. American Economic Review 76, 323-329.

Keister, L. A. 1998. Engineering growth: Business groups structure and firm performance in China's transition economy. American Journal of Sociology, 104(3): 404-440.

Khanna, T., and Palepu, K. (2000a). The future of business groups in emerging markets: Long-run evidence from Chile. Academy of Management journal, 43(3), 268-285. 
Khanna, T., and Palepu, K. (2000b). Is group affiliation profitable in emerging markets? An analysis of diversified Indian business groups. The Journal of Finance, 55(2): 867-891.

Khanna, T., and Rivkin, J. (2001). Estimating the performance effects of business groups in emerging markets. Strategic Management Journal, 22(1): 45-74.

Khanna, T., and Y. Yafeh. (2007). “Business Groups in Emerging Markets: Paragons or Parasites?”. Journal of Economic Literature, 45(2), 331-372.

Khanna, T., and Y. Yafeh. (2005). Business Groups and Risk Sharing around the World. Journal of Business, 78(1), $301-340$.

La Porta, R., Lopez-de-Silanes, and F., Shleifer, A., (1999). Corporate ownership around the world. Journal of Finance 54 (2), 471-518.

Leff, N. H. (1978). Industrial organization and entrepreneurship in the developing countries: The economic groups. Economic development and cultural change, 26(4), 661-675.

Lensink, R., and R. van der Molen (2010), 'Does Group Affiliation Increase Firm Value for Diversified Groups? New Evidence from Indian Companies', Journal of Empirical Finance, 17, 332-44.

Öztürk, Ö. (2012). Türkiye'de firmalar ve sermaye grupları arasındaki bağlantılar: İMKB'de işlem gören firmalar üzerine bir inceleme, 2002-2008. Iktisat Isletme ve Finans, 27(311), 83-112.

Plümper, T., and V. E. Troeger. (2007). Efficient Estimation of Time-Invariant and Rarely Changing Variables in Finite Sample Panel Analyses with Unit Fixed Effects. Political Analysis 15 (2): 124-139.

Plümper, T., and V. E. Troeger. (2011). Fixed-Effects Vector Decomposition: Properties, Reliability, and Instruments. Political Analysis 19 (2): 147-164.

Selcuk, E. A. (2014). Corporate Diversification, Group Affiliation and Firm Value: Evidence from Turkey. Journal of BRSA Banking and Financial Markets, 8(2), 151-174.

Shleifer, A., and Vishny, R. W. (1986). Large shareholders and corporate control. Journal of political economy, 94(3, Part 1), 461-488.

Wooldridge, J. M. (2002). Econometric Analysis of Cross Section and Panel Data. Cambridge: MIT Press.

Zhang, Q. (2011). Diversification and performance of group-affiliated firms during institutional transitions: The case of the Chinese textile industry. American Journal of Economics and Business Administration, 3(2): 234-246. 